\title{
IMPLEMENTASI SURAT EDARAN MAHKAMAH AGUNG NOMOR 4 TAHUN 2016 DALAM PEMBERANTASAN TINDAK PIDANA KORUPSI DI PROVINSI RIAU
}

\author{
Riki Saputra \\ riki_scoof@yahoo.com \\ Magister Ilmu Hukum Universitas Riau \\ ABSTRACT
}

Implementation of the Supreme Court Circular Letter Number 4 of 2016 in the eradication of corruption in Riau Province in terms of proof and pattern of calculating the element of state financial losses is that there is no uniformity. This irregularity can be seen from the fact that there are still calculations of state financial losses calculated by law enforcement agencies, state financial losses calculated by the BPK, and state financial losses calculated by the BPKP. There is no disparity in punishment against the application of the Supreme Court Circular Letter Number 4 of 2016 in the eradication of corruption in Riau Province because of the loss of state finances which were not counted by the BPK, the judges who tried corruption cases at the Pekanbaru District Court did not make free decisions. Or in other words, state financial losses that are not counted by the BPK, are still processed according to the legal provisions that apply when the perpetrators of corruption have been proven guilty legally and convincingly. The tendency of law enforcement agencies to use certain agencies or institutions to declare that there has been a state financial loss caused by the main factor, namely ease of coordination.

Keywords: Implementation, Supreme Court Circular, Corruption, Riau

\section{ABSTRAK}

Implementasi Surat Edaran Mahkamah Agung Nomor 4 Tahun 2016 dalam pemberantasan tindak pidana korupsi di Provinsi Riau ditinjau dari pembuktian dan pola penghitungan unsur kerugian keuangan negara adalah belum terdapat keseragaman. Ketidakseragaman tersebut dapat ditinjau dari masih ada penghitungan kerugian keuangan negara yang dihitung sendiri oleh lembaga penegak hukum, kerugian keuangan negara yang dihitung oleh BPK, dan kerugian keuangan negara yang dihitung oleh BPKP. Tidak terdapat disparitas pemidanaan terhadap diterapkan atau tidak diterapkannya Surat Edaran Mahkamah Agung Nomor 4 Tahun 2016 dalam pemberantasan tindak pidana korupsi di Provinsi Riau karena terhadap kerugian keuangan negara yang tidak dihitung oleh BPK, hakim yang mengadili perkara korupsi pada Pengadilan Negeri Pekanbaru, tidak menjatuhkan putusan bebas. Atau dengan kata lain, kerugian keuangan negara yang tanpa dihitung oleh BPK, tetap diproses sesuai ketentuan hukum yang berlaku pada saat pelaku tindak pidana korupsi telah terbukti bersalah secara sah dan meyakinkan. Kecondongan instansi penegak hukum dalam menggunakan instansi atau lembaga tertentu untuk menyatakan telah terjadinya kerugian keuangan negara disebabkan oleh faktor utama, yaitu kemudahan dalam melakukan koordinasi.

Kata Kunci: Implementasi, Surat Edaran Mahkamah Agung, Tindak Pidana Korupsi, Riau 


\section{PENDAHULUAN}

Korupsi yang menggejala merupakan sebuah bentuk dari bagaimana manusia berkuasa. Hubungan antara perilaku berkuasa dan korupsi begitu dekat. Kekuasaan cenderung untuk disalahgunakan. ${ }^{1}$ Banyak teori bisa digunakan untuk menjelaskan korupsi sebagai persoalan budaya. Di antaranya adalah teori dari Emile Durkheim. Sosiolog Prancis ini memandang bahwa watak manusia sebenarnya bersifat pasif dan dikendalikan oleh masyarakatnya. ${ }^{2}$

Berdasarkan hal tersebut di atas, korupsi terkait dengan berbagai aspek, yaitu

\footnotetext{
${ }^{1}$ Fokky Fuad Wasitaatmadja. 2017. Filsafat Hukum: Akar Religiositas Hukum, Jakarta: Kencana, hlm. 240.

2 Wijayanto dan Ridwan Zachrie (Editor). 2009. Korupsi Mengorupsi Indonesia: Sebab, Akibat, dan Prospek Pemberantasan, Jakarta: Gramedia Pustaka Utama, h. 847. Menurut Yesmil Anwar, era reformasi di Indonesia menjadi ladang yang subur bagi perubahan cepat di pelbagai sektor kehidupan. Perubahan tersebut ada yang bersifat positif karena memang diharapkan oleh masyarakat. Namun, ada pula yang bersifat merusak bahkan sangat meresahkan masyarakat. Buah yang tidak diharapkan oleh masyarakat adalah lahirnya berbagai bentuk kejahatan, yang sebelum reformasi tidak pernah terbayangkan akan terjadi dalam negara yang berfalsafah Pancasila. Betapa tidak, manusia Indonesia yang selama ini merasa dirinya sebagai bangsa yang ramah tamah, penuh welas asih, berubah menjadi makhluk, yang oleh Emile Durkheim disebut sebagai makhluk yang amoral, dan oleh Thomas Hobbes dinamakan homo homini lupus, beringas, kasar dan amat mudah tersinggung. Beberapa bentuk dampak negatif dari perubahan yang cepat dalam era reformasi, misalnya semakin merebaknya kenakalan remaja, penyalahgunaan narkoba dan miras, perjudian, kolusi-korupsi-nepotisme (KKN), pornografi, pelacuran, tawuran, penjarahan, dan brutalisme massa. Lihat: Yesmil Anwar. 2009. Saat Menuai Kejahatan; Sebuah Pendekatan Sosiokultural Kriminologi, Hukum, dan HAM, Bandung: Refika Aditama, hlm. 14.
}

dari aspek kecenderungan untuk menyalahgunakan kekuasaan di samping aspek kebudayaan, yaitu perilaku korupsi disebabkan persoalan budaya yang berlaku di tengah-tengah masyarakat. Korupsi tentunya harus diminimalisir dengan penegakan hukum secara terus menerus. Agar penegakan hukum yang dilakukan terlaksana dengan baik, maka suatu peraturan perundang-undangan, mutlak diperlukan.

Salah satu peraturan perundangundangan $^{3}$ dalam penegakan hukum tindak pidana korupsi adalah Undang-Undang Nomor 20 Tahun 2001 tentang Perubahan atas Undang-Undang Nomor 31 Tahun 1999 tentang Pemberantasan Tindak Pidana Korupsi. Bentuk lainnya adalah Surat Edaran Mahkamah Agung Nomor 4 Tahun 2016 tentang Pemberlakuan Rumusan Hasil Rapat Pleno Kamar Mahkamah Agung Tahun 2016 sebagai Pedoman Pelaksanaan Tugas bagi Pengadilan.

Penerapan sistem kamar di Mahkamah Agung RI salah satunya bertujuan untuk menjaga kesatuan penerapan hukum dan konsistensi putusan. Rapat pleno kamar adalah salah satu

\footnotetext{
3 Yang dimaksud dengan peraturan perundangundangan berdasarkan Pasal 1 angka 2 UndangUndang Nomor 12 Tahun 2011 tentang Pembentukan Peraturan Perundang-undangan, yaitu peraturan tertulis yang memuat norma hukum yang mengikat secara umum dan dibentuk atau ditetapkan oleh lembaga negara atau pejabat yang berwenang melalui prosedur yang ditetapkan dalam Peraturan Perundang-undangan.
} 
instrumen untuk mewujudkan tujuan tersebut. Rumusan hukum hasil rapat pleno kamar adalah pedoman dalam penanganan perkara di Mahkamah Agung serta pengadilan tingkat pertama dan banding sepanjang substansi rumusannya berkenaan dengan kewenangan peradilan tingkat pertama dan banding. ${ }^{4}$

Rumusan Hukum Kamar Pidana, khususnya rumusan hukum dalam rangka penegakan hukum korupsi adalah sebagai berikut:

1. Ketentuan batas waktu 60 hari pengembalian kerugian Negara atas rekomendasi Badan Pemeriksa Keuangan/Badan Pengawasan Keuangan dan Pembangunan/Inspektorat sesuai ketentuan Pasal 20 ayat (3) UndangUndang Nomor 15 Tahun 2004 tentang Pemeriksaan Pengelolaan dan Tanggung Jawab Keuangan Negara tidak berlaku bagi Terdakwa yang bukan Pejabat (Swasta) yang mengembalikan kerugian Negara dalam tenggang waktu tersebut, ketentuan tersebut hanya berlaku bagi Penyelenggara Pemerintahan. Tetapi tidak bersifat mengikat manakala pengembalian kerugian negara oleh

\footnotetext{
${ }^{4}$ Surat Edaran Mahkamah Agung Nomor 4 Tahun 2016 tentang Pemberlakuan Rumusan Hasil Rapat Pleno Kamar Mahkamah Agung Tahun 2016 sebagai Pedoman Pelaksanaan Tugas bagi Pengadilan, hlm. 1-2.
}

Penyelenggara Pemerintahan dilakukan setelah batas waktu 60 hari. Adalah menjadi kewenangan Penyidik melakukan proses hukum apabila ditemukan indikasi Tindak Pidana Korupsi.

2. Instansi yang berwenang menyatakan ada tidaknya kerugian keuangan Negara adalah Badan Pemeriksa Keuangan yang memiliki kewenangan konstitusional sedangkan instansi lainnya seperti Badan Pengawasan Keuangan dan Pembangunan/ Inspektorat/Satuan Kerja Perangkat Daerah tetap berwenang melakukan pemeriksaan dan audit pengelolaan keuangan Negara namun tidak berwenang menyatakan atau mendeclare adanya kerugian keuangan Negara. Dalam hal tertentu Hakim berdasarkan fakta persidangan dapat menilai adanya kerugian Negara dan besarnya kerugian Negara.

3. Manakala Terdakwa tidak pernah hadir di sidang Pengadilan dengan alasan sakit permanen, yang diperkuat dengan surat keterangan Dokter, maka sikap Majelis Hakim yang mengadili dapat memerintahkan dilakukan pemeriksaan kesehatan ulang (second opinion) oleh Tim dokter Rumah Sakit Umum Pusat atau Daerah. 
4. Dalam hal terjadi tindak terlalu sulit, maka hal tersebut sudah pidana/korupsi yang ada kaitannya dengan perkara yang sedang diperiksa secara perdata, maka putusan Perdata tidak mengikat sesuai ketentuan Pasal 3 Peraturan Mahkamah Agung Nomor 1 Tahun $1956,{ }^{5}$ seharusnya tidak menjadi kewenangan BPK.

Terdapat beberapa instansi atau lembaga yang berwenang melakukan perhitungan kerugian negara dalam rangka penegakan hukum pidana Indonesia, khususnya dalam rangka penegakan hukum

Berdasarkan hal tersebut di atas, diketahui bahwa Badan Pemeriksa terhadap tindak pidana korupsi. Untuk lebih Keuangan (BPK) adalah satu-satunya jelasnya, hal tersebut diuraikan sebagai berikut: instansi yang memiliki kewenangan

1. Badan Pemeriksa Keuangan (BPK)

Dasar hukum BPK sebagai lembaga negara yang berwenang menilai dan/atau menetapkan jumlah kerugian negara adalah sebagaimana diatur di dalam Undang-Undang Nomor 15 Tahun 2006 tentang Badan Pemeriksa Keuangan. Berdasarkan Pasal 10 ayat (1) Undang-Undang Nomor 15 Tahun Pengawasan Keuangan dan Pembangunan (BPKP). Dengan demikian, potensi permasalahan adalah apabila instansi yang berwenang menyatakan atau men-declare ada tidaknya kerugian keuangan Negara, mengeluarkan keputusan bahwa tidak terjadi kerugian negara meskipun berdasarkan pemeriksaan instansi lainnya diduga terdapat unsur kerugian negara. Selain itu, permasalahan lainnya adalah apabila pembuktian terhadap kerugian negara tidak

\footnotetext{
5 Surat Edaran Mahkamah Agung Nomor 4 Tahun 2016 tentang Pemberlakuan Rumusan Hasil Rapat Pleno Kamar Mahkamah Agung Tahun 2016 sebagai Pedoman Pelaksanaan Tugas bagi Pengadilan, hlm. 4-5.
}

2006 tentang Badan Pemeriksa Keuangan, diatur ketentuan bahwa BPK menilai dan/atau menetapkan jumlah kerugian negara yang diakibatkan oleh perbuatan melawan hukum baik sengaja maupun lalai yang dilakukan oleh bendahara, pengelola Badan Usaha Milik Negara/Badan Usaha Milik Daerah, dan lembaga atau badan lain yang menyelenggarakan pengelolaan keuangan negara.

2. Badan Pengawasan Keuangan dan Pembangunan (BPKP) 
Dasar hukum BPKP sebagai lembaga negara yang berwenang melakukan penghitungan kerugian keuangan negara adalah sebagaimana diatur di dalam Peraturan Presiden Nomor 192 Tahun 2014 tentang Badan Pengawasan Keuangan dan Pembangunan. Berdasarkan Pasal 27 Peraturan Presiden Nomor 192 Tahun 2014 tentang Badan Pengawasan Keuangan dan Pembangunan, diatur ketentuan bahwa Deputi Bidang Investigasi melaksanakan tugas membantu Kepala di bidang pelaksanaan pengawasan kelancaran pembangunan termasuk program lintas sektoral, pencegahan korupsi, audit atas penyesuaian harga, audit klaim, audit investigatif terhadap kasuskasus penyimpangan yang berindikasi merugikan keuangan negara, audit penghitungan kerugian keuangan negara dan pemberian keterangan ahli.

Penghitungan kerugian keuangan negara kerap menjadi polemik dalam sidang perkara korupsi. Permasalahan yang kerap muncul lembaga mana yang sebenarnya paling berwenang menyatakan ada atau tidaknya kerugian negara. Menjawab polemik ini, Mahkamah Agung (MA) menerbitkan Surat Edaran MA (SEMA) Nomor 4 Tahun 2016. SEMA tersebut mengatur tentang Pemberlakuan Rumusan
Hasil Rapat Pleno Kamar MA Tahun 2016 sebagai Pedoman Pelaksanaan Tugas Bagi Pengadilan. Salah satu poinnya, rumusan kamar pidana (khusus) yang menyatakan hanya Badan Pemeriksa Keuangan (BPK) yang secara konstitusional berwenang mendeclare kerugian keuangan negara. ${ }^{6}$

Menurut Ketua Mahkamah Agung, M Hatta Ali, penuntut umum sering meminta penghitungan kerugian negara kepada BPKP karena lebih cepat dan keberadaan BPK yang tidak sampai ke pelosok-pelosok daerah kabupaten/kota. Namun demikian, untuk menentukan kerugian negara, sangat diminta ke BPK karena lebih tepat. Hatta mengakui rumusan SEMA No. 4 Tahun 2016 tidak selamanya mengikat hakim. Siapapun yang memeriksa kerugian negara, baik BPK maupun BPKP, tidak harus diikuti hakim. Demikian pula dengan ahli. Jika ada ahli yang berpendapat tidak ada kerugian negara, hakim juga tidak berkewajiban untuk mengikuti. Sebab, menurut Hatta, hakim bisa berpendapat sendiri, meski pada prinsipnya rumusan hasil pleno kamar yang tertuang dalam SEMA mengikat para hakim. "SEMA ini tidak selamanya mengikat para hakim, tidak

\footnotetext{
6 Novrieza Rahmi, Siapa Berwenang Menyatakan Kerugian Negara? SEMA Pun Tak Mengikat - Hakim bisa berpendapat sendiri. Para penegak hukum juga tidak khawatir dengan terbitnya SEMA No. 4 Tahun 2016, dalam: http://www.hukumonline.com/berita/ baca/lt58ac1253a9228/siapa-berwenang-menyatakankerugian-negara-sema-pun-tak-mengikat, diakses tanggal 13 Juni 2017.
} 
harus sama persis (seperti yang ada dalam rumusan SEMA), dilihat dulu kasus per kasus (kasuistis)," ujarnya. ${ }^{7}$

Menurut Kepala Biro Hukum dan Humas MA, Ridwan Mansyur, tak jarang penghitungan BPK berbeda dengan penghitungan BPKP dalam lingkup kerugian negara. Selama ini hasil audit BPK dan hasil BPKP berbeda-beda. Bahkan, pihak terdakwa dengan kesaksian (keterangan ahli) meringankan mengajukan auditor independen. Oleh karena itu, terbitnya SEMA bertujuan untuk kesamaan dan percepatan pengurusan perkara korupsi. ${ }^{8}$

Berdasarkan hal tersebut di atas, diketahui bahwa muncul persoalan terkait penghitungan kerugian negara setelah diterbitkannya Surat Edaran Mahkamah Agung Nomor 4 Tahun 2016 tentang Pemberlakuan Rumusan Hasil Rapat Pleno Kamar Mahkamah Agung Tahun 2016 sebagai Pedoman Pelaksanaan Tugas bagi Pengadilan. Persoalan tersebut muncul karena pada kenyataannya, lembaga selain BPK juga memiliki kewenangan untuk melakukan penghitungan kerugian negara. Oleh karena itu, penulis tertarik mengangkat persoalan ini, terutama tentang kedudukan dan dasar filosofis diterbitkannya Surat Edaran Mahkamah Agung Nomor 4 Tahun 2016 tentang Pemberlakuan Rumusan Hasil Rapat Pleno Kamar Mahkamah Agung

\footnotetext{
${ }^{7}$ Ibid.

${ }^{8}$ Ibid.
}

Tahun 2016 sebagai Pedoman Pelaksanaan Tugas bagi Pengadilan.

Penetapan Surat Edaran Mahkamah Agung Nomor 4 Tahun 2016 tentang Pemberlakuan Rumusan Hasil Rapat Pleno Kamar Mahkamah Agung Tahun 2016 sebagai Pedoman Pelaksanaan Tugas bagi Pengadilan, tentunya dapat berpengaruh terhadap penegakan hukum tindak pidana korupsi, khususnya pada tahap penyidikan dan penuntutan yang dilakukan oleh jaksa/penuntut umum. Hal ini disebabkan sebelum penetapan Surat Edaran Mahkamah Agung Nomor 4 Tahun 2016 tersebut di atas, penetapan kerugian negara dapat dilakukan oleh BPK atau BPKP. Untuk lebih jelasnya, diuraikan 2 (dua) contoh kasus sebagai berikut:

1. Berdasarkan putusan pengadilan tindak pidana korupsi pada Pengadilan Negeri Pekanbaru Nomor: 17/Pid.Sus/Tipikor/2016/ＰN.PBR, tanggal 9 Juni 2016, lembaga yang menyatakan adanya kerugian negara adalah Badan Pemeriksa Keuangan (BPK)-RI Perwakilan Provinsi Riau.

2. Berdasarkan putusan Mahkamah Agung Nomor: 263 K/Pid.Sus/2016, tanggal 16 Mei 2016, yang memperbaiki amar putusan pengadilan tindak pidana korupsi pada Pengadilan Tinggi Pekanbaru Nomor: 24/Pid.Sus.TPK/ 2015/PT.PBR, 
tanggal 24 November 2015 yang menguatkan putusan pengadilan tindak pidana korupsi pada Pengadilan Negeri Pekanbaru

Nomor: 31/Pid.Sus.TPK/2015/PN.PBR, tanggal 3 September 2015, lembaga yang menyatakan adanya kerugian negara adalah Badan Pengawas Keuangan dan Pembangunan (BPKP) Perwakilan Provinsi Riau.

Pasca penetapan Surat Edaran Mahkamah Agung Nomor 4 Tahun 2016 tentang Pemberlakuan Rumusan Hasil Rapat Pleno Kamar Mahkamah Agung Tahun 2016 sebagai Pedoman Pelaksanaan Tugas bagi Pengadilan, maka untuk menghindari lolosnya pelaku tindak korupsi dari tuntutan hukum, jaksa/penuntut umum, seperti para jaksa/penuntut umum di Kejaksaan Negeri Rokan Hulu sudah berupaya agar pernyataan kerugian negara dinyatakan oleh Badan Pemeriksa Keuangan (BPK)-RI Perwakilan Provinsi Riau. Salah satu upaya lolosnya pelaku tindak korupsi tersebut dari tuntutan hukum adalah melakukan eksepsi terhadap hanya Badan Pemeriksa Keuangan yang berhak menyatakan kerugian negara.

Akan tetapi, upaya para jaksa/penuntut umum di Kejaksaan Negeri Rokan Hulu agar pernyataan kerugian negara oleh pelaku tindak pidana korupsi dinyatakan oleh Badan Pemeriksa Keuangan (BPK)-RI Perwakilan Provinsi Riau, tidak dapat dilaksanakan secara optimal karena jangka waktu proses penghitungan kerugian negara yang dilakukan oleh Badan Pemeriksa Keuangan (BPK)-RI Perwakilan Provinsi Riau lebih lama apabila dibandingkan dengan jangka waktu proses penghitungan kerugian negara yang dilakukan oleh Badan Pengawas Keuangan dan Pembangunan (BPKP) Perwakilan Provinsi Riau. Hal ini (khususnya apabila proses penghitungan kerugian negara yang dilakukan oleh Badan Pemeriksa Keuangan (BPK)-RI Perwakilan Provinsi Riau) pada akhirnya akan menimbulkan kesan penanganan perkara korupsi yang lambat sehingga secara tidak langsung berdampak pada tingkat kepercayaan masyarakat terhadap pemberantasan tindak pidana korupsi di Indonesia pada umumnya, dan tingkat kepercayaan masyarakat terhadap pemberantasan tindak pidana korupsi di wilayah Provinsi Riau pada khususnya.

Institusi yang seringkali dilibatkan oleh penegak hukum dalam menghitung kerugian negara adalah Badan Pemeriksa Keuangan (BPK) dan Badan Pengawasan Keuangan dan Pembangunan (BPKP). Di luar kedua institusi tersebut misalkan penghitungan kerugian negara juga dapat dilakukan oleh akuntan publik. Bahkan dalam beberapa perkara pihak Kejaksaan 
dan Pengadilan pernah melakukan sendiri penghitungan kerugian keuangan negara. ${ }^{9}$

Salah satu alternatif pihak yang dapat melakukan perhitungan kerugian keuangan negara adalah akuntan sebagai suatu profesi. Pendapat ini disampaikan oleh Leo Nugroho. Menurutnya, penghitungan kerugian negara hanya dapat dilakukan oleh profesi akuntan. Karena akuntan mempunyai standar profesi yang cukup untuk melakukan penghitungan kerugian keuangan negara. Instansi atau lembaga yang melakukan penghitungan bisa lembaga apa saja, sejauh yang melakukan penghitungan adalah orang yang mempunyai kompetensi sebagai akuntan. Meskipun menurut UndangUndang yang berwenang melakukan perhitungan adalah BPK, namun tidak semua pegawai BPK bisa melakukan penghitungan. Untuk dapat melakukan penghitungan harus orang yang mempunyai kompetensi yang disebutkan di atas, yaitu yang berprofesi sebagai akuntan. ${ }^{10}$

Dari uraian di atas, penulis tertarik melakukan penelitian tentang kerugian keuangan negara, baik dari aspek hukum pembuktian dan aspek hukum lainnya, dengan judul penelitian, yaitu:

"Implementasi Surat Edaran Mahkamah

\footnotetext{
9 Abdul Fatah, Nyoman Serikat Putra Jaya, dan Henny Juliani. 2017. Kajian Yuridis Penerapan Unsur Merugikan Keuangan Negara dalam Penegakan Hukum Tindak Pidana Korupsi, Diponegoro Law Journal Volume 6, Nomor 1, hlm. 7. ${ }^{10}$ Ibid., hlm. 7.
}

Agung Nomor 4 Tahun 2016 dalam Pemberantasan Tindak Pidana Korupsi di Provinsi Riau".

Berdasarkan hal tersebut di atas, dirumuskan masalah sebagai berikut: Pertama, bagaimana implementasi Surat Edaran Mahkamah Agung Nomor 4 Tahun 2016 dalam pemberantasan tindak pidana korupsi di Provinsi Riau ditinjau dari pembuktian dan pola penghitungan unsur kerugian keuangan negara? Kedua, apakah terdapat disparitas pemidanaan terhadap diterapkan atau tidak diterapkannya Surat Edaran Mahkamah Agung Nomor 4 Tahun $2016 ?$

\section{METODE PENELITIAN}

Jenis dari penelitian ini adalah penelitian sosiologis yuridis. Penelitian ini bersifat deskriptif. Penelitian ini dilaksanakan di Propinsi Riau dengan mengambil sampel di beberapa wilayah hukum kejaksaan negeri yang ada di Provinsi Riau. Populasi dalam penelitian ini adalah para kepala seksi tindak pidana khusus di wilayah hukum kejaksaan negeri yang berada di Provinsi Riau dan hakim pada pengadilan tindak pidana korupsi Pekanbaru. Sampel dalam penelitian ini adalah sebagian anggota populasi, yaitu 3 (tiga) orang kepala seksi tindak pidana khusus di wilayah hukum kejaksaan negeri yang berada di Provinsi Riau dan 3 (tiga) 
orang hakim pada pengadilan tindak pidana disajikan pada tabel di bawah ini.

korupsi Pekanbaru yang selengkapnya

Tabel 1

Populasi dan Sampel

\begin{tabular}{|c|l|c|c|c|}
\hline No & \multicolumn{1}{|c|}{ Klasifikasi Populasi } & $\begin{array}{c}\text { Jumlah } \\
\text { Populasi } \\
\text { (orang) }\end{array}$ & $\begin{array}{c}\text { Jumlah } \\
\text { Sampel } \\
\text { (orang) }\end{array}$ & $\begin{array}{c}\text { Persentase } \\
(\%)\end{array}$ \\
\hline 1. & $\begin{array}{l}\text { Kepala Seksi Tindak Pidana Khusus di } \\
\text { Wilayah Hukum Kejaksaan Negeri yang } \\
\text { Ada di Provinsi Riau }\end{array}$ & 12 & 3 & $25 \%$ \\
\hline 2 & $\begin{array}{l}\text { Hakim Pengadilan Tindak Pidana Korupsi } \\
\text { Pekanbaru }\end{array}$ & 6 & 3 & $50 \%$ \\
\hline \multicolumn{1}{|l|}{ Jumlah } & 18 & 6 & $33 \%$ \\
\hline
\end{tabular}

Sumber: Data Olahan Lapangan Tahun 2018.

Berdasarkan tabel di atas, sampel dari pihak kepala seksi tindak pidana khusus di wilayah hukum kejaksaan negeri yang ada di Provinsi Riau di dalam penelitian ini terdiri dari kepala seksi tindak pidana khusus pada Kejaksaan Negeri Pekanbaru, pada Kejaksaan Negeri Rokan Hulu (kerugian negara dihitung oleh BPKP), dan pada Kejaksaan Negeri Kuantan Singingi (kerugian negara dihitung oleh BPK).

Data yang digunakan dalam penelitian ini adalah data primer dan data sekunder. Data primer adalah data utama yang diperoleh peneliti dari responden penelitian. Dalam penelitian ini, data primer tersebut bersumber dari hasil wawancara. Data sekunder adalah data yang diperoleh dari buku-buku literatur yang mendukung dengan pokok masalah yang dibahas. Data sekunder dalam penelitian ini adalah data yang diperoleh dari peraturan perundangundangan dan buku-buku literatur yang memiliki kajian mendukung dengan permasalahan penelitian.

Teknik pengumpulan data dalam penelitian ini dilakukan dalam tiga bentuk. Pertama adalah observasi. Kedua, dalam bentuk wawancara. Ketiga, dalam bentuk studi dokumen. Analisis data dalam penelitian ini dilakukan secara kualitatif, yaitu menguraikan data secara jelas dan terperinci. Metode penarikan kesimpulan dalam penelitian ini dilakukan secara deduktif, yaitu penarikan kesimpulan dari hal yang bersifat umum kepada hal yang bersifat khusus.

\section{HASIL PENELITIAN}

\section{A. Implementasi SEMA No. 4 Tahun 2016}

Terkait dengan pertanyaan, sebutkan instansi atau lembaga apa saja yang melakukan perhitungan kerugian negara dalam rangka penegakan hukum pidana terhadap tindak pidana korupsi di daerah 
hukum Pengadilan Tindak Pidana Korupsi pada Pengadilan Negeri Pekanbaru, baik sebelum maupun setelah adanya Surat Edaran Mahkamah Agung Nomor 4 Tahun 2016, Yanuar Anadi, selaku hakim tindak pidana korupsi pada Pengadilan Negeri Pekanbaru, memberikan jawaban, yaitu BPK dan BPKP sebagai instansi atau lembaga yang melakukan perhitungan kerugian negara. ${ }^{11}$ Atas pertanyaan yang sama, Yuriza Antoni, Kasi Pidsus pada Kejaksaan Negeri Pekanbaru, memberikan jawaban antara lain sebagai berikut: Dalam penghitungan unsur kerugian keuangan negara dalam pembuktian tindak pidana korupsi, Kejari Pekanbaru tidak berpatokan pada SEMA Nomor 4 Tahun 2016 yang menyebutkan bahwa Instansi yang berwenang menyatakan ada tidaknya kerugian keuangan Negara adalah Badan Pemeriksa Keuangan yang memiliki kewenangan konstitusional, artinya badanbadan audit lain selain BPK, tidak berwenang menyatakan ada atau tidaknya kerugian negara. ${ }^{12}$ Secara faktual implementatif, BPK, Jaksa penuntut Umum, masih menggunakan analogi "kerugian

\footnotetext{
11 Hasil wawancara dengan Yanuar Anadi, Hakim Pengadilan Negeri Pekanbaru, wawancara dilakukan pada tanggal 5 Desember 2018.

${ }_{12}$ Hasil wawancara dengan Yuriza Antoni, Kasi Pidsus Kejaksaan Negeri Pekanbaru, wawancara dilakukan pada tanggal 7 Desember 2018.
}

negara" sama dengan "kerugian keuangan negara". 13

Terkait dengan pertanyaan, hambatan dalam pelaksanaan tugas dan wewenang dikaitkan dengan perhitungan kerugian negara oleh instansi atau lembaga terkait, baik sebelum maupun setelah adanya Surat Edaran Mahkamah Agung Nomor 4 Tahun 2016, Hendri, selaku hakim tindak pidana korupsi pada Pengadilan Negeri Pekanbaru, menyatakan bahwa tidak terdapat hambatan dalam pelaksanaan tugas dan wewenang dikaitkan dengan perhitungan kerugian negara oleh instansi atau lembaga terkait, baik sebelum maupun setelah adanya Surat Edaran Mahkamah Agung Nomor 4 Tahun 2016. ${ }^{14}$ Terhadap pertanyaan yang sama, Yendri Aidil Fiftha, Kasi Pidsus pada Kejaksaan Negeri Kuantan Singingi, memberikan jawaban sebagai berikut: Seksi tindak pidana khusus Kejaksaan Negeri Kuantan Singingi dalam penanganan perkara tindak pidana korupsi tidak memiliki hambatan, hal ini beralasan karena semua putusan perkara tindak pidana korupsi pada tahun 2016-2017 terdakwa divonis bersalah oleh hakim dan dinyatakan

\footnotetext{
13 Hernol Ferry Makawimbang. 2014. Kerugian Keuangan Negara dalam Tindak Pidana Korupsi, Suatu Pendekatan Hukum Progresif, Yogyakarta: Thafa Media, hlm. 24.

14 Hasil wawancara dengan Hendri, Hakim Pengadilan Negeri Pekanbaru, wawancara dilakukan pada tanggal 5 Desember 2018.
} 
merugikan keuangan negara. $^{15}$ Hal ini menurut penulis telah tercapai suatu kebenaran di persidangan.

Menurut M. Yahya Harahap, hukum mengendalikan keadilan. Keadilan yang dikehendaki hukum harus mencapai nilai; persamaan, hak asasi individu, kebenaran, kepatuhan, dan melindungi masyarakat. ${ }^{16}$

Berdasarkan data dari Kepaniteraan Pengadilan Negeri Pekanbaru, pada tahun 2016, terdapat 34 perkara tindak pidana korupsi (Polri 24 perkara dan kejaksaan 10 perkara) yang diadili di Pengadilan Negeri Pekanbaru. Dari jumlah tersebut, sebanyak 3 perkara, unsur kerugian keuangan negara dihitung oleh BPK, sebanyak 28 perkara, unsur kerugian keuangan negara dihitung oleh BPKP, dan sebanyak 3 perkara, unsur kerugian keuangan negara dihitung oleh inspektorat.

Selanjutnya, berdasarkan data yang penulis peroleh dari Kepaniteraan Pengadilan Negeri Pekanbaru, diketahui bahwa pada tahun 2017, terdapat 22 perkara tindak pidana korupsi (Polri 8 perkara dan kejaksaan 14 perkara) yang diadili di Pengadilan Negeri Pekanbaru. Dari jumlah tersebut, sebanyak 16 perkara, unsur kerugian keuangan negara dihitung oleh BPKP, sebanyak 5 perkara, unsur kerugian

\footnotetext{
${ }^{15}$ Hasil wawancara dengan Yendri Aidil Fiftha, Kasi Pidsus Kejari Kuantan Singingi, wawancara dilakukan pada tanggal 9 Nopember 2018.

${ }^{16}$ Alvi Syahrin. 2009. Beberapa Masalah Hukum, Medan: Sofmedia, 2009, h. 3-4.
}

keuangan negara dihitung oleh inspektorat, dan 1 perkara, unsur kerugian keuangan negara dihitung oleh Auditor Independent. Pada tahun 2017, tidak terdapat satu perkara pun yang dihitung unsur kerugian keuangan negaranya oleh BPK.

Dari hal tersebut di atas, penulis berpendapat bahwa ada atau tidaknya implementasi dari Surat Edaran Mahkamah Agung Nomor 4 Tahun 2016, hal tersebut tidak merubah semangat pemberantasan korupsi di Provinsi Riau. Hal itu karena meskipun bukan BPK sebagai lembaga yang menyatakan ada atau tidaknya kerugian keuangan negara, perkara korupsi tetap diperiksa dan diputus oleh majelis hakim di pengadilan.

Menurut Beverley Earle and Anita Cava, corruption is a global problem (korupsi adalah masalah global) ${ }^{17}$ Terkait hal tersebut, Carl J. Friedrich menyatakan corruption is deviant behavior associated with a particular motivation, namely that of private gain at public expense (korupsi adalah perilaku menyimpang yang terkait dengan motivasi tertentu, yaitu keuntungan pribadi dengan biaya publik). ${ }^{18}$

\footnotetext{
${ }^{17}$ Beverley Earle and Anita Cava. 2015. The Mystery of Declinations Under the Foreign Corrupt Practices Act: A Proposal to Incentivize Compliance, Symposium: Corruption and Compliance: Promoting Integrity in a Global Economy, 49 U.C. Davis L. Rev. 567, Westlaw (C) 2018 Thomson Reuters, h. 10.

${ }^{18}$ John Mukum Mbaku. 2016. International Law and the Fight Against Bureaucratic Corruption in Africa, Arizona Journal of International and Comparative
} 
Menurut Stuart Vincent Campbell, the problem of corruption can be traced back to the far reaches of human history (masalah korupsi dapat ditelusuri kembali ke jauh dari sejarah manusia). ${ }^{19}$ Oleh karena itu, menurut Philip M. Nichols, understanding corruption is imperative for legal scholarship (memahami korupsi sangat penting untuk para cendikiawan hukum) ${ }^{20}$ Sehingga Leslie Gielow Jacobs and Benjamin B. Wagner berpendapat, various strategies have proliferated to combat the plague of public corruption (berbagai strategi telah menjamur untuk memerangi wabah korupsi). ${ }^{21}$

Terkait dengan pertanyaan, solusi mengatasi hambatan dalam pelaksanaan tugas dan wewenang dikaitkan dengan perhitungan kerugian negara oleh instansi atau lembaga terkait, baik sebelum maupun setelah adanya Surat Edaran Mahkamah Agung Nomor 4 Tahun 2016, M. Suryadi, selaku hakim tindak pidana korupsi pada

Law, 33 Ariz. J. Int'1 \& Comp. L. 661, Westlaw (C) 2018 Thomson Reuters, h. 3.

19 Stuart Vincent Campbell. 2013. Perception Is Not Reality: The Fcpa, Brazil, and the Mismeasurement of Corruption, 22 Minn. J. Int'l L. 247, Minnesota Journal of International Law, Westlaw (C) 2018 Thomson Reuters, h. 1.

${ }^{20}$ Philip M. Nichols. 2012. The Psychic Costs of Violating Corruption Laws, 45 Vand. J. Transnat'l L. 145, Vanderbilt Journal of Transnational Law, January, Westlaw @ 2018 Thomson Reuters, h. 1.

${ }^{21}$ Leslie Gielow Jacobs and Benjamin B. Wagner. 2007. Limits to the Independent Anti-Corruption Commission - Model of Corruption Reform: Lessons from Indonesia, Symposium: Rethinking Corruption: An Interdisciplinary Look at a Fundamental Problem, 20 Pac. McGeorge Global Bus. \& Dev. L.J. 327, Pacific McGeorge Global Business \& Development Law Journal, Westlaw @ 2018 Thomson Reuters, h. 1.
Pengadilan Negeri Pekanbaru, memberikan jawaban: Surat Edaran Mahkamah Agung Nomor 4 Tahun 2016 tidaklah mengikat seperti halnya undang-undang. Oleh karena itu, apabila terjadi hambatan dalam pelaksanaannya maka solusi mengenai hal tersebut telah diketahui dengan pasti. ${ }^{22}$ Oleh karena itu, sudah tepat apa yang dinyatakan Peter Mahmud Marzuki, yaitu peran pemerintah dan pengadilan sangat penting dalam menjaga kepastian hukum. ${ }^{23}$ Berbicara tentang hakim dan putusan hakim di Indonesia tidak bisa dilepaspisahkan dari pembicaraan tentang keadilan dan kepastian hukum. $^{24}$

Kepastian hukum menurut penulis merupakan suatu kebutuhan yang mendasar bagi setiap subjek hukum dalam memainkan peranannya dalam kehidupan bermasyarakat dan bernegara, sehingga dengan adanya kepastian hukum tersebut, subjek hukum dapat melakukan hubungan hukum dengan siapapun tanpa adanya kekhawatiran.

Terkait dengan pertanyaan, solusi mengatasi hambatan dalam pelaksanaan tugas dan wewenang dikaitkan dengan perhitungan kerugian negara oleh instansi

\footnotetext{
22 Hasil wawancara dengan M. Suryadi, Hakim Pengadilan Negeri Pekanbaru, wawancara dilakukan pada tanggal 5 Desember 2018.

23 Peter Mahmud Marzuki. 2009. Pengantar Ilmu Hukum, Jakarta: Prenada Media Group, h. 159.

${ }^{24}$ Antonius Sudirman. 2007. Hati Nurani Hakim dan Putusannya: Suatu Pendekatan dari Perspektif Ilmu Hukum Perilaku (Behavioral Jurisprudence) Kasus Hakim Bismar Siregar, Bandung: Citra Aditya Bakti, h. 44 .
} 
atau lembaga terkait, baik sebelum maupun setelah adanya Surat Edaran Mahkamah Agung Nomor 4 Tahun 2016, Herlambang Saputro, Kasi Pidsus pada Kejaksaan Negeri Rokan Hulu, memberikan jawaban sebagai berikut: Modus operandi tindak pidana korupsi dalam perkembangannya mengalami perubahan, untuk mengatasi hal tersebut perlu dilakukannya koordinasi dan pelatihan terhadap aparat penegak hukum dengan melibatkan auditor BPK, BPKP dan lainnya guna meningkatkan senirgisitas penegak hukum dalam menghitung kerugian negara. ${ }^{25}$

Menurut penulis, terdapat perbedaan pola penghitungan kerugian keuangan negara dalam rangka implementasi Surat Edaran Mahkamah Agung Nomor 4 Tahun 2016 dalam pemberantasan tindak pidana korupsi di Provinsi Riau. Sebagai contoh, dalam penegakan hukum di Pekanbaru dan di Kuantan Singingi, penegak hukum lebih condong kepada BPKP sebagai lembaga yang menyatakan kerugian keuangan negara. Sedangkan di Rokan Hulu, penegak hukum lebih condong kepada instansi sendiri sebagai lembaga yang menyatakan kerugian keuangan negara.

\section{Menurut penulis, kecondongan} instansi penegak hukum dalam menggunakan instansi atau lembaga yang berwenang untuk

25 Hasil wawancara dengan Herlambang Saputro, Kasi Pidsus Kejari Rokan Hulu, wawancara dilakukan pada tanggal 2 Nopember 2018. menyatakan telah terjadinya kerugian keuangan negara disebabkan oleh faktor utama, yaitu koordinasi. Dalam hal tertentu satu instansi dinyatakan mudah untuk berkoordinasi sehingga perkara diselesaikan dengan cepat. Sebaliknya, karena koordinasi yang sulit, dampaknya adalah penyelesaian perkara yang berlangsung lama.

Menurut penulis, hambatan dalam pemberantasan tindak pidana korupsi di Provinsi Riau, khususnya terkait dengan implementasi Surat Edaran Mahkamah Agung Nomor 4 Tahun 2016 adalah sebagai berikut: Pertama, menjadi celah bagi pelaku tindak pidana korupsi, yang antara lain mengajukan eksepsi dan praperadilan atas dasar SEMA tersebut. Ssalah satu putusan yang menarik untuk dilakukan kajian dalam konteks ini adalah putusan praperadilan pada Pengadilan Negeri Pasir Pengaraian Nomor 5/Pid.Prap/2018PN.Prp. Salah satu pertimbangan hukum dalam putusan tersebut adalah hakim menilai unsur kerugian negara menjadi syarat mutlak salah satu dari dua alat bukti sebagai bukti permulaan yang cukup untuk menetapkan status tersangka atas seseorang yang diduga melakukan tindak pidana korupsi. Kedua, legal problem dalam konteks semangat pemberantasan korupsi, salah satunya adalah siapa yang berwenang melakukan pengujian terhadap substansi SEMA tersebut, yaitu apakah sudah sesuai dengan semangat pemberantasan korupsi atau 
sebaliknya. Ketiga, sebagai salah satu dasar pelaku tindak pidana korupsi agar lolos dari jeratan hukum.

Menurut penulis, sebaiknya dibuat peraturan bersama antara lembaga penegak hukum dalam rangka menyatukan semangat pemberantasan korupsi dalam konteks lembaga yang berwenang menyatakan kerugian keuangan negara. Hal ini menurut penulis pada akhirnya akan memberikan suatu kepastian hukum dalam pelaksanaan pemberantasan korupsi. Selain itu, apa pun bentuk kebijakan secara sektoral yang dibuat oleh lembaga penegak hukum pidana (kepolisian, kejaksaan, pengadilan) seharusnya mengacu pada aturan yang berlaku.

Selain itu, penulis berpendapat, seharusnya dilaksanakan pelatihan bagi aparat penegak hukum pada lembaga penyidikan dalam lingkup penghitungan kerugian keuangan negara sehingga dapat mempercepat proses pemeriksaan perkara karena lembaga penyidikan tersebut sudah memiliki auditor sendiri dalam menghitung kerugian keuangan negara. Selanjutnya, seharusnya hal yang sangat prinsip sifatnya, tidak diatur di dalam bentuk surat edaran, peraturan, dan lain sebagainya. Akan tetapi, hal tersebut diatur di dalam bentuk undangundang. Pada awalnya, dapat saja dinyatakan bahwa surat edaran dan peraturan tersebut ditetapkan dengan dalih mengisi kekosongan hukum atau mengisi tertinggalnya hukum dibanding perkembangan masyarakat. Akan tetapi, apabila hal tersebut tidak diatur dengan kekuatan hukum yang lebih tinggi derajatnya, maka kekuatan hukum kebijakan tersebut akan mengalami permasalahan pada tahap implementasinya.

Menurut penulis, apabila dibandingkan dengan Peraturan Mahkamah Agung Nomor 2 Tahun 2012 tentang Batasan Tindak Pidana Ringan dan Jumlah Denda dalam KUHP, maka apa yang diatur di dalam Surat Edaran Mahkamah Agung Nomor 4 Tahun 2016, belum begitu perlu untuk diatur dalam rangka pemberantasan tindak pidana korupsi di Indonesia pada umumnya, dan pemberantasan tindak pidana korupsi di Provinsi Riau pada khususnya.

\section{B. Disparitas Pemidanaan}

Umumnya koordinasi oleh KPK dilakukan dengan Kepolisian dan Kejaksaan. Namun, Laporan Tahunan KPK juga menyebutkan instansi lain yang berwenang dalam pemberantasan korupsi seperti BPK, BPKP, Inspektorat Jenderal Departemen dan Nondepartemen. ${ }^{26}$ Pada dasarnya, besarnya kerugian negara tidak boleh ditetapkan dengan dikira-kira atau

26 Theodorus M. Tuanakotta. 2014. Menghitung Kerugian Keuangan Negara dalam Tindak Pidana Korupsi, Jakarta: Salemba Empat, h. 40. 
ditaksir. $^{27}$ Menurut Herlambang Saputro, selaku Kasipidsus Kejari Rokan Hulu, terkait dengan pertanyaan: Bagaimana disparitas terhadap diterapkan atau tidak diterapkannya Surat Edaran Mahkamah Agung Nomor 4 Tahun 2016 dalam pemberantasan tindak pidana korupsi di Pengadilan Negeri Pekanbaru? Diberikan tanggapan sebagai berikut: Surat Edaran Mahkamah Agung Nomor 4 Tahun 2016 tidak mempunyai kekuatan hukum. Selanjutnya harapan pasca pemberlakuan Surat Edaran Mahkamah Agung tersebut adalah setelah Surat Edaran Mahkamah Agung tersebut sudah tidak sesuai lagi dengan perkembangan pembuktian saat ini, maka Mahkamah Agung dapat kembali memperbaiki atau membuat Surat Edaran Mahkamah Agung dengan menyesuaikan perkembangan hukum saat ini. Selanjutnya perlu dibuat rule yang membatasi perhitungan kerugian negara yang boleh dilakukan oleh Penyidik, BPK, BPKP atau auditor lainnya, dimana instansi atau badan tersebut mempunyai tujuan yang mulia, yakni pengembalian kerugian negara. ${ }^{28}$ Tujuan utama dari hal ini menurut penulis adalah terwujudnya kepastian hukum.

27 Theodorus M. Tuanakotta. 2014. Akuntansi Forensik dan Audit Investigatif, Jakarta: Salemba Empat, h. 866.

28 Hasil wawancara dengan Herlambang Saputro, Kasi Pidsus Kejari Rokan Hulu, wawancara dilakukan pada tanggal 2 Nopember 2018.
Menurut Suteki, apabila kepastian hukum ditempatkan sebagai nilai yang diutamakan, maka kepastian hukum ini akan menggeser nilai kegunaan dan nilai keadilan ke samping karena yang utama bagi kepastian hukum adalah adanya peraturan itu sendiri. Tentang apakah peraturan itu harus adil dan memiliki kegunaan bagi masyarakatnya, adalah di luar pengutamaan nilai kepastian hukum. ${ }^{29}$ Hal serupa juga dikemukakan oleh Roni Wiyanto, yang menyebutkan bahwa yang utama bagi kepastian hukum adalah adanya peraturan itu sendiri. ${ }^{30}$ Pada abad yang lalu di Eropa dianut suatu pendapat bahwa hakim itu hanyalah mulut undang-undang. ${ }^{31}$ Kepastian hukum selalu mempersoalkan hubungan hukum antara warga negara dan negara. ${ }^{32}$ Ada empat hal yang berhubungan dengan makna kepastian hukum, salah satunya adalah hukum itu positif. ${ }^{33}$ Menurut Satjipto Rahardjo, kepastian hukum adalah hal yang tidak sederhana, karena teks undang-undang yang secara eksplisit mengatakan tidak

\footnotetext{
${ }^{29}$ Dinal Fedrian, Elza Faiz, Hermansyah, Imran dan Suwantoro (Editor). 2012. Dialektika Pembaruan Sistem Hukum Indonesia, Jakarta: Sekretariat Jenderal Komisi Yudisial Republik Indonesia, h. 271.

30 Roni Wiyanto. 2012. Asas-asas Hukum Pidana Indonesia, Bandung: Mandar Maju, h. 60.

31 Andi Hamzah. 2010. Hukum Acara Pidana Indonesia, Jakarta: Sinar Grafika, h. 114-115.

${ }^{32}$ Muhamad Erwin. 2013. Filsafat Hukum: Refleksi Kritis terhadap Hukum, Jakarta: RajaGrafindo Persada, h. 65.

${ }^{33}$ Achmad Ali. 2009. Menguak Teori Hukum (Legal Theory) \& Teori Peradilan (Judicialprudence): Termasuk Interpretasi Undang-undang (Legisprudence) Volume I Pemahaman Awal, Jakarta: Prenada Media Group, h. 292-293.
} 
boleh ditambah dan dikurangi pun masih saja bisa diberi makna lain. ${ }^{34}$ Menurut Saifullah, keadilan dan kepastian hukum adalah dua tujuan hukum yang kerapkali tidak sejalan dan sulit dihindarkan dalam praktek hukum. ${ }^{35}$

Pada hakikatnya, penegakan hukum bertujuan untuk mewujudkan ketertiban dan kepastian hukum dalam masyarakat yang berintikan keadilan. Kepastian hukum tanpa didasarkan pada sendi-sendi keadilan akan menimbulkan ketidakpuasan dan mengundang banyak reaksi. ${ }^{36}$ Secara faktual, penegakan hukum sangat sulit memenuhi tiga unsur, yaitu kepastian hukum, keadilan, dan kemanfaatan hukum secara simultan. Acapkali dijumpai dimana kepastian hukum mendesak keadilan, maupun kemanfaatan, dan demikian sebaliknya. ${ }^{37}$

Penanganan kasus korupsi, terbagi dalam beberapa penanganan, salah satunya menggunakan ukuran nilai kerugian negara. ${ }^{38}$ Penyidikan kasus korupsi dimiliki oleh tiga lembaga penegak hukum, yaitu

34 Satjipto Rahardjo. 2010. Penegakan Hukum Progresif, Jakarta: Kompas Media Nusantara, h. 64.

35 Saifullah. 2010. Refleksi Sosiologi Hukum, Bandung: Refika Aditama, h. 81.

36 Alfitra. 2012. Hapusnya Hak Menuntut dan Menjalankan Pidana, Bogor: Raih Asa Sukses, h. 17.

${ }^{37}$ Heri Tahir. 2010. Proses Hukum yang Adil dalam Sistem Peradilan Pidana di Indonesia, Yogyakarta: LaksBang PRESSindo, h. 98-99.

38 J.E. Sahetapy (Penanggung Jawab/Komisioner). 2011. Pemantauan dan Pengkajian Legislasi serta Permasalahan Aktual di Bidang Hukum (Suatu Rekomendasi), Jakarta: Komisi Hukum Nasional RI, 2011, h. 76. kepolisian, kejaksaan, dan KPK. Khusus bagi KPK dibatasi pada kasus korupsi yang minimal kerugian negara sejumlah Rp. 1 milyar. ${ }^{39}$ Menurut penulis, ${ }^{40}$ pengembalian kerugian negara adalah sesuatu hal yang juga menimbulkan permasalahan.

Peran Peraturan Mahkamah Agung (PERMA) dan Surat Edaran Mahkamah Agung (SEMA) dapat didudukkan sebagai sebuah perangkat tingkah laku yang dimiliki Mahkamah Agung yang berfungsi sebagai pedoman hukum dalam penertiban, pengaturan, pengisi kekosongan hukum, dan penciptaan hukum dalam konteks pengembangan hukum Indonesia. Peranan PERMA dan SEMA sangat penting dalam konteks pengembangan hukum di Indonesia

39 Mohammad Fajrul Falaakh (Penyunting). 2009. Akar-akar Mafia Peradilan di Indonesia (Masalah Akuntabilitas Penegak Hukum), Jakarta: Komisi Hukum Nasional RI, h. 15.

${ }^{40}$ Berdasarkan penelusuran dokumentasi hukum yang penulis lakukan, sebelum Undang-Undang Nomor 20 Tahun 2001 tentang Perubahan atas Undang-Undang Nomor 31 Tahun 1999 tentang Pemberantasan Tindak Pidana Korupsi, diberlakukan sebagai hukum positif, berdasarkan Surat Jaksa Agung Muda Bidang Tindak Pidana Khusus Nomor: B-051/F/Fpt.2/1/1991, tanggal 17 Januari 1991, tentang Tuntutan Pembayaran Uang Pengganti dalam Perkara Tindak Pidana Korupsi, disebutkan bahwa tuntutan pembayaran uang pengganti sebagaimana dimaksud dalam ketentuan Pasal 34 sub c. UU. No. 3 Tahun 1971 dalam pelaksanaannya ternyata masih belum ada keseragaman. Berdasarkan penelusuran dokumentasi hukum yang penulis lakukan, berdasarkan Surat Edaran Jaksa Agung Nomor: SE004/J.A/8/1988, tanggal 5 Agustus 1988, tentang Pelaksanaan Pidana Tambahan Pembayaran Uang Pengganti, disebutkan bahwa kerugian Negara akibat tindak pidana korupsi belum dapat dikembalikan sepenuhnya kepada Negara. Hal tersebut disebabkan karena masih adanya hambatan-hambatan yang dihadapi sejak tahap penyidikan, penuntutan dan terutama dalam pelaksanaan eksekusi perkara-perkara tindak pidana korupsi. 
yang dapat digunakan oleh Mahkamah Agung sebagai wahana judge made law hakim membentuk hukum. ${ }^{41}$

Ada perbedaan antara PERMA dan SEMA baik dari segi pihak yang berwenang membuatnya, objek pengaturannya, maupun struktur penyusunannnya. PERMA dikeluarkan oleh Ketua Mahkamah Agung terhadap permasalahan teknis yudisial, terutama dalam mengisi kekosongan hukum, atau terhadap keberlakuan undang-undang yang belum ada peraturan organiknya, yang struktur susunannya menyerupai struktur perumusan undang-undang. Sedangkan SEMA dapat dikeluarkan oleh unsur pimpinan lain selain ketua yang bersifat kebijakan-kebijakan nonteknis, walaupun tidak sedikit SEMA yang substansinya mengatur kebijakan penerapan hukum teknis. struktur susunannya lebih menyerupai surat biasa, sesuai namanya. Namun PERMA memang memiliki keunggulan tersendiri dibandingkan SEMA baik dari segi jangkauan, daya mengikat maupun tingkat kebutuhan mendesaknya. ${ }^{42}$

\section{KESIMPULAN}

1. Implementasi Surat Edaran Mahkamah Agung Nomor 4 Tahun 2016 dalam pemberantasan tindak pidana korupsi di Provinsi Riau ditinjau dari pembuktian

\footnotetext{
${ }^{41}$ H. M. Fauzan. 2015. Peranan PERMA \& SEMA dalam Pengembangan Hukum Indonesia menuju Peradilan yang Agung, Jakarta: Prenada Media, h. vii.

${ }^{42}$ Ibid., h. vii-viii.
}

dan pola penghitungan unsur kerugian keuangan negara adalah belum terdapat keseragaman. Ketidakseragaman tersebut dapat ditinjau dari masih ada penghitungan kerugian keuangan negara yang dihitung sendiri oleh lembaga penegak hukum, kerugian keuangan negara yang dihitung oleh BPK, dan kerugian keuangan negara yang dihitung oleh BPKP.

2. Tidak terdapat disparitas pemidanaan terhadap diterapkan atau tidak diterapkannya Surat Edaran Mahkamah Agung Nomor 4 Tahun 2016 dalam pemberantasan tindak pidana korupsi di Provinsi Riau karena terhadap kerugian keuangan negara yang tidak dihitung oleh BPK, hakim yang mengadili perkara korupsi pada Pengadilan Negeri Pekanbaru, tidak menjatuhkan putusan bebas. Atau dengan kata lain, kerugian keuangan negara yang tanpa dihitung oleh BPK, tetap diproses sesuai ketentuan hukum yang berlaku pada saat pelaku tindak pidana korupsi telah terbukti bersalah secara sah dan meyakinkan.

\section{REFERENSI}

Alfitra. 2012. Hapusnya Hak Menuntut dan Menjalankan Pidana, Bogor: Raih Asa Sukses.

Ali, Achmad. 2009. Menguak Teori Hukum (Legal Theory) \& Teori Peradilan 
(Judicialprudence): $\quad$ Termasuk Interpretasi Undang-undang (Legisprudence) Volume I Pemahaman Awal, Jakarta: Prenada Media Group.

Anwar, Yesmil. 2009. Saat Menuai Kejahatan; Sebuah Pendekatan Sosiokultural Kriminologi, Hukum, dan HAM, Bandung: Refika Aditama.

Campbell, Stuart Vincent. 2013. Perception Is Not Reality: The Fcpa, Brazil, and the Mismeasurement of Corruption, 22 Minn. J. Int'l L. 247, Minnesota Journal of International Law, Westlaw (C) 2018 Thomson Reuters.

Earle, Beverley and Cava, Anita. 2015. The Mystery of Declinations Under the Foreign Corrupt Practices Act: A Proposal to Incentivize Compliance, Symposium: Corruption and Compliance: Promoting Integrity in a Global Economy, 49 U.C. Davis L. Rev. 567, Westlaw (C) 2018 Thomson Reuters.

Erwin, Muhamad. 2013. Filsafat Hukum: Refleksi Kritis terhadap Hukum, Jakarta: RajaGrafindo Persada.

Falaakh, Mohammad Fajrul (Penyunting). 2009. Akar-akar Mafia Peradilan di Indonesia (Masalah Akuntabilitas Penegak Hukum), Jakarta: Komisi Hukum Nasional RI.

Fatah, Abdul., Jaya, Nyoman Serikat Putra., dan Juliani, Henny. 2017. Kajian Yuridis Penerapan Unsur Merugikan Keuangan Negara dalam Penegakan Hukum Tindak Pidana Korupsi, Diponegoro Law Journal Volume 6, Nomor 1.

Fauzan, H. M. 2015. Peranan PERMA \& SEMA dalam Pengembangan
Hukum Indonesia mепији Peradilan yang Agung, Jakarta: Prenada Media.

Fedrian, Dinal., Faiz, Elza., Hermansyah, Imran dan Suwantoro (Editor). 2012. Dialektika Pembaruan Sistem Hukum Indonesia, Jakarta: Sekretariat Jenderal Komisi Yudisial Republik Indonesia.

Hamzah, Andi. 2010. Hukum Acara Pidana Indonesia, Jakarta: Sinar Grafika.

Jacobs, Leslie Gielow and Wagner, Benjamin B.. 2007. Limits to the Independent Anti-Corruption Commission Model of Corruption Reform: Lessons from Indonesia, Symposium: Rethinking Corruption: An Interdisciplinary Look at a Fundamental Problem, 20 Pac. McGeorge Global Bus. \& Dev. L.J. 327, Pacific McGeorge Global Business \& Development Law Journal, Westlaw (C) 2018 Thomson Reuters.

Makawimbang, Hernol Ferry. 2014. Kerugian Keuangan Negara dalam Tindak Pidana Korupsi, Suatu Pendekatan Hukum Progresif, Yogyakarta: Thafa Media.

Marzuki, Peter Mahmud. 2009. Pengantar Ilmu Hukum, Jakarta: Prenada Media Group.

Mbaku, John Mukum. 2016. International Law and the Fight Against Bureaucratic Corruption in Africa, Arizona Journal of International and Comparative Law, 33 Ariz. J. Int'1 \& Comp. L. 661, Westlaw (C) 2018 Thomson Reuters.

Nichols, Philip M. 2012. The Psychic Costs of Violating Corruption Laws, 45 Vand. J. Transnat'l L. 145, Vanderbilt Journal of Transnational 
Law, January, Westlaw (C) 2018 Thomson Reuters.

Novrieza Rahmi, Siapa Berwenang Menyatakan Kerugian Negara? SEMA Pun Tak Mengikat - Hakim bisa berpendapat sendiri. Para penegak hukum juga tidak khawatir dengan terbitnya SEMA No. 4 Tahun 2016, dalam: http://www.hukumonline.com/berit a/ baca/lt58ac1253a9228/siapaberwenang-menyatakan-kerugiannegara-sema-pun-tak-mengikat, diakses tanggal 13 Juni 2017.

Rahardjo, Satjipto. 2010. Penegakan Hukum Progresif, Jakarta: Kompas Media Nusantara.

Sahetapy,

J.E.

(Penanggung Jawab/Komisioner). 2011. Pemantauan dan Pengkajian Legislasi serta Permasalahan Aktual di Bidang Hukum (Suatu Rekomendasi), Jakarta: Komisi Hukum Nasional RI.

Saifullah. 2010. Refleksi Sosiologi Hukum, Bandung: Refika Aditama.

Sudirman, Antonius. 2007. Hati Nurani Hakim dan Putusannya: Suatu Pendekatan dari Perspektif Ilmu Hukum Perilaku (Behavioral Jurisprudence) Kasus Hakim Bismar Siregar, Bandung: Citra Aditya Bakti.

Surat Edaran Mahkamah Agung Nomor 4 Tahun 2016 tentang Pemberlakuan Rumusan Hasil Rapat Pleno Kamar Mahkamah Agung Tahun 2016 sebagai Pedoman Pelaksanaan Tugas bagi Pengadilan.

Syahrin, Alvi. 2009. Beberapa Masalah Hukum, Medan: Sofmedia, Medan.

Tahir, Heri. 2010. Proses Hukum yang Adil dalam Sistem Peradilan Pidana di
Indonesia, Yogyakarta: LaksBang PRESSindo.

Tuanakotta, Theodorus M. 2014. Akuntansi Forensik dan Audit Investigatif, Jakarta: Salemba Empat.

Tuanakotta, Theodorus M. 2014. Menghitung Kerugian Keuangan Negara dalam Tindak Pidana Korupsi, Jakarta: Salemba Empat

Undang-Undang Nomor 12 Tahun 2011 tentang Pembentukan Peraturan Perundang-undangan.

Wasitaatmadja, Fokky Fuad. 2017. Filsafat Hukum: Akar Religiositas Hukum, Jakarta: Kencana.

Wijayanto dan Zachrie, Ridwan (Editor). 2009. Korupsi Mengorupsi Indonesia: Sebab, Akibat, dan Prospek Pemberantasan, Jakarta: Gramedia Pustaka Utama.

Wiyanto, Roni. 2012. Asas-asas Hukum Pidana Indonesia, Bandung: Mandar Maju. 


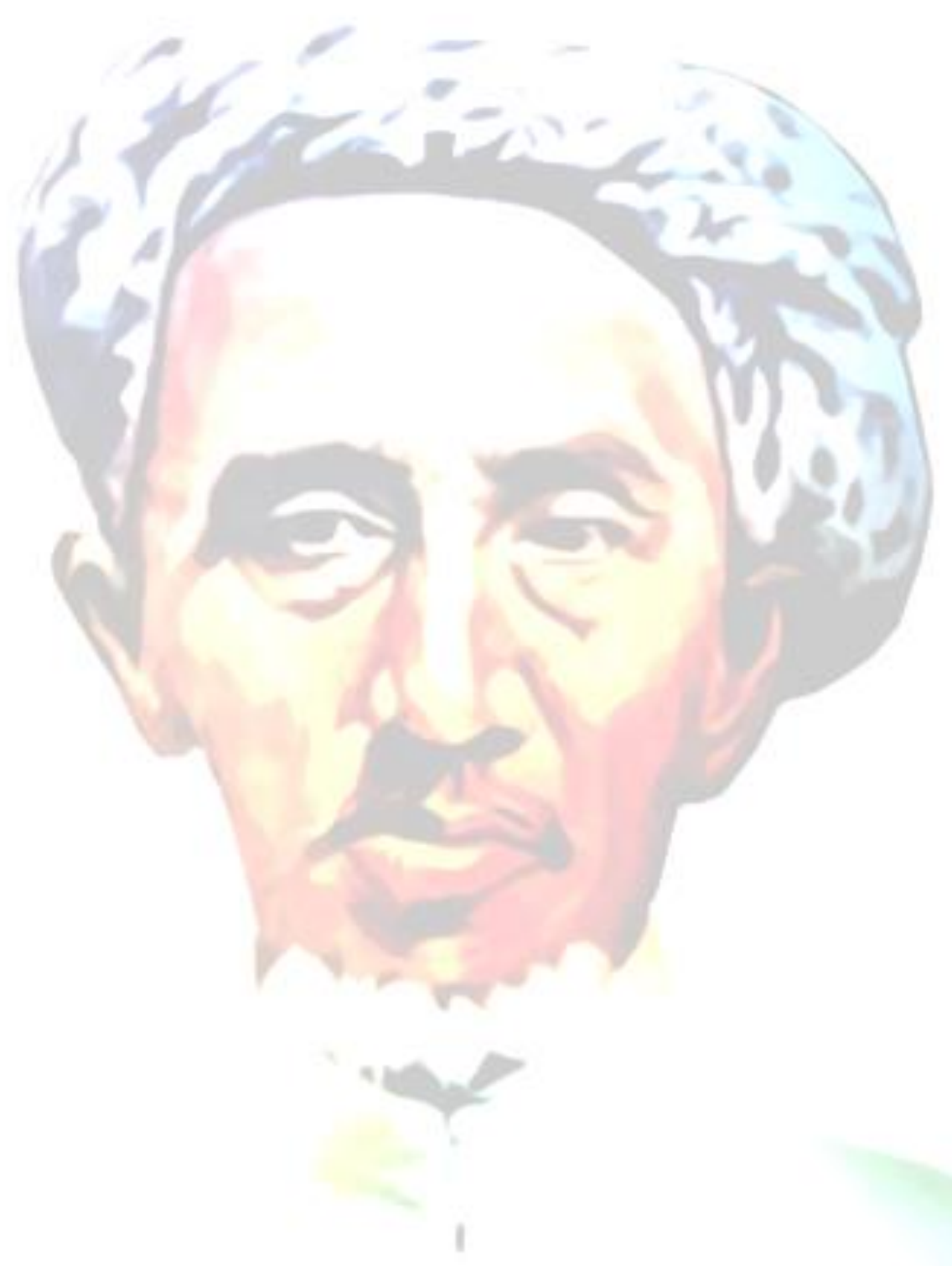

